DOI: $10.1515 /$ rpp-2017-0018

$\mathrm{PhD}$ in Pedagogical Sciences, Associate Professor, LARYSA MOVCHAN Vinnytsia Training and Research Institute of Economics of TNEU Address: 37 Honta St., Vinnytsia, 21000, Ukraine E-mail: seawave2202@mail.ru

$\mathrm{PhD}$ in Pedagogical Sciences, Associate Professor, INNA ZARISHNIAK Vinnytsia Training and Research Institute of Economics of TNEU Address: 37 Honta St., Vinnytsia, 21000, Ukraine E-mail: zarishnyak@mail.ru

\title{
THE ROLE OF ELECTIVE COURSES IN STUDENTS' PROFESSIONAL DEVELOPMENT: FOREIGN EXPERIENCE
}

\begin{abstract}
The article considers the role of elective courses in professional development of students of economics. Modern European education is developing on the principles of democratization and humanization, where democratization implies the involvement of all agents/participants of the education process into forming its content and solving numerous related problems. Moreover, in order to be competitive in global labour market, modern specialists must develop such features as mobility, cultural, language and religious empathy, professionalism, commitment to the human virtues, etc. The content of education expressed in the curriculum is now not a rigid unity. Offering elective courses, university curricula can be easily modified to the students' needs and aspirations. The analysis of the curricula of the economic faculties at some leading European universities has showed a great amount of elective courses mainly in general subjects such as Psychology, Pedagogy, Philosophy, History, Politology, Social Science, etc. These courses make up approximately $10 \%$ of the total study load and are meant to realize interdisciplinary links, deepen students' understanding of economic phenomena and develop analytical and strategic thinking. On the one hand, by choosing elective courses students are more agitated in learning, more interested and motivated. On the other hand, universities think harder over the supply of subjects and their content. At the same time, it increases lecturers' motivation to consider new approaches, update information, and on the whole do their best to make their subjects appealing to students. The research has proved that elective courses realize an important role in students' professional and personal development by integrating knowledge of many subjects, through their participation in tailoring the curricula and enriching their professional portfolio.

Keywords: elective courses, curriculum, professional portfolio, education content, professional development, personal development, tailoring the curriculum.
\end{abstract}

\section{INTRODUCTION}

The issue of education content is not new, yet it has always been subject to changes under the influence of numerous societal, political, ideological and economic factors that caused educational reforms. Higher education is the stage where students can and should influence the subject content according to their personal and professional interests with regard to their future labour activity. Nowadays, during rapid economic changes, the efforts of our country to occupy a dignified place in the world progressive 
community, the issue of improving education standards and bringing them in the conformity with the standards of the developed countries is of major importance.

Nowadays education systems of the European countries are developing on the principles of democratization and humanization, where democratization implies the involvement of all agents/participants of the pedagogic process into forming its content and solving numerous related problems. Humanization of education aims to develop a new generation with such characteristic features as mobility, cultural, language and religious empathy, professionalism, commitment to the human virtues, etc. These two principles of democratization and humanization of education are focused on a personality, therefore students have the right to express their needs and build their future professional profile themselves, either by choosing desired subjects necessary for their future professional activity or actively participating in modifying the curriculum.

A lot of universities provide the students with the opportunity to choose from the alternative subjects which mostly refer to general electives, while other restrict to only compulsory courses arguing that general subjects (to which refer mainly humanities) are not necessary for economic, medical or technical education.

Some scholars argue that students can be misled by the variety of appealing subjects and ignore the more complicated thus less interesting, in their opinion disciplines. We will try to have a closer look at the problem.

\section{THE AIM OF THE STUDY}

The aim of the study is to define the principles of selecting alternative courses at foreign universities and determine the role of elective courses in students' professional development.

\section{THEORETICAL FRAMEWORK AND RESEARCH METHODS}

The research is based on the works of both national and foreign authors. M. Beerkens-Soo has tackled the general issues of higher education from the international perspective. R. Donnelly, M. Fitzmaurice, G. Parry, V. Sjostrand, V. Slastionin and others have studied the content of education. V. Sjostrand (1967) considers the content of education as two interrelated processes, namely, training and upbringing that develop a personality according to the social and cultural demand of the society. According to V. Slastonin, I. Isaiev \& E. Shiianov (2002), education should be considered as a phenomenon that evolves under the impact of a certain social context to conform to societal needs at a definite time period. D. Chapman (1981) has studied the factors of students' selecting a higher education institution and what makes universities attractive for students. R. Beswick (1973), M. Hedges, G. Pacheco \& D. Webber (2014) have analyzed higher education modularization and the factors influencing students' choice of subjects to study. R. Donnelly \& M. Fitzmaurice (2006) have studied the principles of module design. I. Bim (2005) stresses the importance of students' involvement in constructing an educational context according to their interests and needs. The article also presents the results of the analysis and synthesis of the recent reports on higher education and university curricula with regard to the demands of labour market and personal experience. The students' motivation factor in choosing elective courses, as well as the role of elective courses in students' professional development is in the centre of the study. The syllabi of some European economic universities (Lund University, The University of Vienna, The University of Copenhagen and The University of Dublin) have been analyzed as for the elective content and some comparisons with current situation at Ukrainian economic faculties have been made, based on which relevant suggestions have been put forward. 


\section{RESULTS}

Universities are now trying to improve and upgrade their level of training by offering a wide range of subjects that cover various topics of the subject sphere. Students are now more involved in the education process by participating in curriculum design, choosing some subjects to study either at their home university or by an exchange program, so that universities may adjust to their growing needs. Since education was declared as a service, all universities compete for students and students compete for better universities. Thus, R. Beswick (1973) indicated that the economic survival of a college or university depends on students' selecting the appropriate institution and successfully completing the program; consequently, institutions should attempt to attract those students who will succeed.

Two decades ago there was a switch to a modular system. Modularization of education started in Great Britain in the 1960s when universities trying to raise their rates offered the elective courses, increased the student's participation, their flexibility and mobility (Bell \& Wade 1993). This caused numerous discussions among the university teachers, educational bodies and governments. On the one hand, it enhanced students' learning opportunities and made universities provide relevant subjects and elaborate their content. On the other hand, lecturers try to consider new approaches, update information and on the whole strive to make their subjects appealing to students. Nevertheless, there are debates whether this really works. According to D. Chapman (1981), students' aspirations of a high level of education at a college or university play a very important role and are among the decisive factors of students' choice of a university.

R. Beswick (1973) argued that among the factors of influencing the students' choice during the enrollment are reputation of program, specialized programs offered, variety of courses offered, student/professor ratio and family tradition.

In Ukraine, most universities offer courses, which are traditionally divided into compulsory and optional, and students study 6 courses at a time. There is no praxis of choosing this or that course by students themselves, although linguistic faculties offer additional languages for study. We can say the same about the teachers' choice, where students subscribe to a certain course only basing on the feedback of other students or teachers about this lecturer. So, the model of elective courses is only beginning to operate in our country. Naturally, when the combination of disciplines is successful, both a student and a university can benefit from it. According to S. Hofert (2016), a new setting at a faculty can have a remarkable impact on the personality development. The scholar points out that it is difficult to put up with a new atmosphere, especially for a first-year student whose personality is still unstable. For example, at the faculties of marketing and distribution the atmosphere is noisier, livelier (more extraverted) while at the faculties of Finance, Accounting or IT, it is quieter (more introverted). The student must take it into consideration while choosing disciplines as well. On the other hand, the department of human resources must learn more of psychology and understand that a good team is made of different people. There are different reasons why people choose these or those professions. It does not deal only with graduation grades, family tradition or interests. It is the personality that highlights certain features and strongpoints. Therefore, prior to compiling the content of education and offering some subjects, the university should study this psychological coherence and benefit from it. S. Hofert (2016) suggests a so-called subject mix, especially for specialists of humanities, who can combine philosophy with economics or information science, or whatsoever. In such a way they can contribute more to their personal development and to the development of the community where they will work. 
One of the possible solutions to this problem with students' participation is modular system of education. One of the steps of designing modules is considering learner support (Donnely \& Fitzmaurice, 2006). In this respect, a modular system of education enables the students to try themselves in other subjects and broaden the scope of their education. There are a lot of advantages of a modular and credit system. First of all, it concerns the recognition of diplomas among certain countries, especially when students participate in exchange programs or wish to combine their study at different universities. L. Walker (1994) says that modular education enables students to use the skills obtained in one discipline in another and thus reduce boundaries between disciplines. This holds true especially in the modern job setting when each professional needs to have additional skills. For example, doctors need to know informatics to be able to operate sophisticated computerized equipment or to make computer-aided reports and case histories. Economists and managers also need to have computer skills as well as foreign languages to be able to communicate with clients online, make money operations online and follow the events at a stock exchange. Therefore, universities must ensure the most suitable combination of subjects in order to avoid fragmentation. For this purpose the curriculum should contain compulsory subjects with set requirements to their completion or to their entrance. It is also necessary to introduce recommendations from the lecturers for certain students to the selection of modules (Walker, 1994).

Nevertheless, the popularity of rounded education is growing and many universities try to broaden the range of subjects with foreign languages, management courses, history and cultural science. Moreover, it has become popular to add pedagogy even to non-pedagogic professions. The University College of Dublin offers students two selective modules during each academic year, which means one-sixth of the annual module load. These modules are taken either from their core or external programs. For instance, engineering students can take English Literature or Arts students can take Physics. On the total, each faculty offers at least $10 \%$ of selective modules. The reasons students choose non-program modules are different, still among the most frequent are: 1) new experiences; 2) a more appealing CV with a wide range of skills (Hennessy, Hernandez, \& Kieran, 2010).

Here we must point out a negative, in our opinion, tendency to take away some courses, such as pedagogical science or psychology from either compulsory or optional content of training specialists in economics. Although almost all Ukrainian universities train Masters who presumably will pursue a scientific career and obtain a $\mathrm{PhD}$ in economics and further teach at universities, they do not offer any subjects that will train them in professional pedagogy, teaching methods or psychology. The same concerns more specific subjects, where students obtain necessary skills to be able to start work without a long probation period.

A variable component of professional education is one of the ways of its democratization. Introducing a wider range of elective courses at Ukrainian universities will ensure the academic freedom of the participants of the education process. First, choosing a course, the student has a chance for manifestation of their own aspirations. Second, elective courses enable to develop students' virtual goals, motivate them to study and shape their professional image. Third, elective courses promote the realization of principles of organization of education in Ukraine, such as equal conditions for everyone to develop their talents and abilities; humanization and democratization of higher education of Ukraine and its integration into the European educational space while preserving positive progressive traditions and achievements of higher education (Bim, 2005). Then, elective courses also promote students' mobility since they broaden the scope of educational content. And the last, which is seldom mentioned while tailoring curricula for universities, 
elective courses help students comprehend such compulsory specific subjects as Marketing Strategy, Ethical Leadership in Business, Strategic Planning, International Marketing, Advertising Management, History of Economics, Political economy, Economic theory, Management of human resources etc. They help develop communicative competency which implies the ability to listen to other people, understand their opinions, participate in discussions, support or object to opinions, work in a team, understand other people's needs, persuade and encourage.

We must here take a look back some 10 years ago when numerous Bachelor programs included such disciplines as rhetoric, ethnology and even ethics. Unfortunately, most economic universities have excluded these subjects in favour of more specific ones that directly relate to the students' future professional activity. However, there is more than professionally specific component in higher education. In our opinion, university graduates must not only perform well at work, but also contribute to the whole society and do it based on integral knowledge of history, human psychology and national peculiarities. For example, in Finland, students can "take other courses developing citizenship and work skills, or pursue recreational studies" (Beerkens \& Vossensteyn, 2009). We consider as positive the experience of school of Economics and Management of Lund University (Sweden), where the Program of International Business includes 30 credits of elective courses (16\% of the total credits), which comprise International Business Strategy (15 credits) and International exchange studies with either completion of the International Degree Project (15 credits), or Internship (Lund Program, 2016). "The course of International Business Strategy both broadens and deepens the students' knowledge, skills, and judgment in relation to international business. New concepts associated with (mainly international) strategic management are introduced, but at the same time the course provides an integration of previous courses from a strategic perspective" (Lund Program, 2016). This course is taught in Semester 6 and also realizes interdisciplinary links in the economic education, encourage the students synthesize and analyze obtained knowledge during the previous years of study.

The program of Bachelor in Economics at the University of Copenhagen for the academic year 2017/2018 has already planned an elective course Science of Behaviour Change (7,5 credits), which will embrace 42 hours of lectures and 162 hours of preparation. Within the frames of this course students will gain "a deeper understanding of what motivates people, how they process information, and what non-economic features of the choice environment influence decisions" (University of Copenhagen, 2017). The author of the program also explains the students the necessity of this course and how they will apply this knowledge "to identify human biases and creatively design behavioural interventions, policies or products that help people make better decisions" (University of Copenhagen, 2017).

The University of Vienna in the Master Program for Economics also offers a list of elective/alternative compulsory courses under the name of General electives that comprise Political Economy, Economy of the Enterprise, Econometrics and Statistics, Social Science, Politology, Philosophy, International Development, History and Economic History, History of Economic Theory, Mathematics and Operation Research, Law, Geography, Psychology. Students must choose 2 of these courses (Universität Wien, 2013).

All this mentioned above only proves the fact that students of economic, technical, agrarian or medical universities must learn humanities to apply the knowledge of a man in professional situations during professional interaction, observance, teamwork, supervision, management. Students of economics can take advantage of the theory of personality, the hierarchy of human needs, peculiarities of human psychic processes and conditions which will enable them to conduct market research, develop advertising techniques, perform 
management functions. Students can be intrigued by the mechanisms of memorizing, recognizing, guessing which will later help them in further studies and manage the accumulated life experience in future. The knowledge of genetic, gender and age peculiarities of a personality will help the student to cope with stress at work, prevent stressful situations, understand the moods of the co-workers, form the productive staff by employing compatible workers and even raise the company's spirit. These issues are considered in such topic as "Personality in business" where the psychological features of economic agents are revealed, as well as in the course on Pedagogy and Psychology which studies personality characteristic features in relation with certain professional conditions and requirements. In such a ways students may determine if they fit in the future professional setting or need to do some amendments in their program (change a faculty, take additional courses etc.). The elective course on Pedagogy and Psychology lays theoretic basis for the development of a competitive personality who will be able to adjust to the changing job requirements, labour force mobility or life long learning. The knowledge of history will help the students integrate the laws of economic development with historic processes and understand the interrelation of social and economic events in future.

According to the estimations, elective courses help develop general education competencies, such as cognitive competency, which helps to integrate knowledge of various subjects, develop abstract thinking, take well-informed decisions and evaluate own performance. For instance, "Dutch students perform very well in terms of finding a job that corresponds to their skills level and the rate of return of their studies (Bologna Key Statistics). In this respect, the Netherlands outperforms the diversified systems. The data, of course, only shows the averages and there is no information if particular student groups (e.g. the "top" group) would gain from a different system" (Beerkens \& Vossensteyn, 2009).

\section{CONCLUSIONS}

On the basis of the analysis of the pedagogical literature and our own experience, we can state that introducing elective courses as an opportunity for the students to tailor their professional portfolio will contribute to students' professional and personal development and enhance their motivation to perform well in the elected subjects. At the same time, students' involvement into tailoring the curriculum will show the path to its improvement, finding new approaches to teaching, assessment, make higher education institutions more attractive for foreign students and will broaden the scope of education.

Further research will be needed into the ways of adjusting humanities with the respect of their more practical embedding into professional training, thus harmonizing interdisciplinary links. It will be also important to learn the vision of Ukrainian students on the curriculum so that to take steps towards its improvement.

\section{REFERENCES}

1. Bell, G., \& Wade, W. (1993). Modular course design in Britain: some problems, issues and opportunities. Journal of further and higher education, 17 (1), 3-12.

2. Beerkens-Soo, M., \& Vossensteyn, H. (2009). Higher education issues and trends from an international perspective. Netherlands: Centre for higher education policy studies.

3. Beswick, R. (1973). A study of factors associated with student choice in the university selection process. (Doctoral thesis). University of Lethbridge, Lethbridge.

4. Bim, I. L. (2005). Modernizatsiya strukturyi i soderzhaniya shkolnogo yazyikovogo obrazovaniya (IYa). Inostrannyie yazyiki v shkole, 8, 2-6. 
5. Chapman, D. W. (1981). A model of student college choice. Journal of higher education, 52 (5), 490-505.

6. Donnelly, R., \& Fitzmaurice, M. (2006). Designing modules for learning. In S. Moore O'Neill, B. McMullin, (Eds.), Emerging issues in the practice of university learning and teaching (pp. 99-110). Dublin: All Ireland society for higher education (AISHE).

7. Hedges, M., Pacheco, G. A., \& Webber, D. J. (2014). What determines students' choices of elective modules? Economics working paper series, 1307. Bristol: University of the West of England.

8. Hennessy, E., Hernandez, M. R., \& Kieran, P. (2010). Teaching and learning across disciplines: student and staff experiences in a newly modularized system. Teaching in higher education, 15 (6), 675-689.

9. Hofert, S. (2016). Stärken \& Studium: Wie sich Persönlichkeit in der Studienwahl zeigen. Retrieved from http://karriereblog.svenja-hofert.de/2016/05/staerken-undstudienwahl-wie-sich-persoenlichkeit-in-der-studienwahl-zeigen/

10. Lund University. (2016). Programme syllabus for BSC programme in international business, Lund University: school of economics and management. Retrieved from http://lusem.lu.se/staff-pages/media/studies/bsc/curriculum/egibu_16_eng.pdf.

11. Sjostrand, W. (1967). Recent trends and developments in primary and secondary education In Scandinavia. International review of education (Revue Internationale de l'Education), 13 (2), 180-194.

12. Slastonin, V. A., Isaev, I. F., \& Shiyanov, E. N. (2002). Pedagogika. Moscow: Izdatelskiy tsentr "Akademiya".

13. Universität Wien. (2013). Curriculum für das Masterstudium Volkswirtschaftslehre, Studienjahr 2012/2013. Retrieved from http://studentpoint.univie.ac.at/fileadmin/user upload/studentpoint_2011/Curricula/Master/MA_Volkswirtschaftslehre.pdf.

14. University of Copenhagen. (2017). $\bar{A} \varnothing K A 08218 U$. Science of behavior change, 2017-2018. Retrieved from http://kurser.ku.dk/course/a\%C3\% 98ka08218u/2017-2018.

15. Verkhovna rada Ukrainy. (2017). Zakon Ukrainy pro vyshchu osvitu. Retrieved from http://zakon2.rada.gov.ua/laws/show/1556-18.

16. Walker, L. (1994). The new higher education systems, modularity and student capability. In A. Jenkins, L. Walker, (Eds.), Developing student capability through modular courses. London: Kogan Page. 